\section{The use of fluorescence in situ hybridization in the diagnosis of hidden mosaicism: apropos of three cases of sex chromosome anomalies}

\author{
O uso da hibridação in situ com fluorescência no \\ diagnóstico de mosaicismo oculto: a propósito de três \\ casos de anomalias de cromossomos sexuais
}

Andréa Trevas Maciel-Guerra',2, Juliana De Paulo', Ana Paula Santos', Guilherme Guaragna-Filho ${ }^{3}$, Juliana Gabriel Ribeiro Andrade ${ }^{1,2}$, Adriana Aparecida Siviero-Miachon ${ }^{4}$, Ângela Maria Spinola-Castro4, Gil Guerra-Júnior ${ }^{2,3}$

\section{SUMMARY}

FISH has been used as a complement to classical cytogenetics in the detection of mosaicism in sex chromosome anomalies. The aim of this study is to describe three cases in which the final diagnosis could only be achieved by FISH. Case 1 was an 8-year-old 46,XY girl with normal female genitalia referred to our service because of short stature. FISH analysis of lymphocytes with probes for the $X$ and $Y$ centromeres identified a 45, $X / 46, X, i d i c(Y)$ constitution, and established the diagnosis of Turner syndrome. Case 2 was a 21 -month-old $46, X Y$ boy with genital ambiguity (penile hypospadias, right testis, and left streak gonad). FISH analysis of lymphocytes and buccal smear identified a 45,X/46,XY karyotype, leading to diagnosis of mixed gonadal dysgenesis. Case 3 was a 47,XYY 19-year-old boy with delayed neuromotor development, learning disabilities, psychological problems, tall stature, small testes, elevated gonadotropins, and azoospermia. FISH analysis of lymphocytes and buccal smear identified a 47,XYY/48,XXYY constitution. Cases 1 and 2 illustrate the phenotypic variability of the 45,X/46,XY mosaicism, and the importance of detection of the $45, X$ cell line for proper management and follow-up. In case 3 , abnormal gonadal function could be explained by the $48, \mathrm{XXYY}$ cell line. The use of FISH in clinical practice is particularly relevant when classical cytogenetic analysis yields normal or uncertain results in patients with features of sex chromosome aneuploidy. Arq Bras Endocrinol Metab. 2012;56(8):545-51

\section{SUMÁRIO}

FISH tem sido usado como um complemento para a citogenética clássica na detecção de mosaicismo em anomalias de cromossomos sexuais. O objetivo deste trabalho é descrever três casos nos quais o diagnóstico final só foi obtido por meio de FISH. $\mathrm{O}$ caso 1 é uma menina de 8 anos, 46,XY, com genitália feminina normal, encaminhada ao nosso setor devido à baixa estatura. A análise de linfócitos por FISH com sondas centroméricas de $\mathrm{X}$ eY identificou a constituição $45, X / 46, X, i d i c(Y)$ e estabeleceu o diagnóstico de síndrome deTurner. $O$ caso 2 é um menino de 21 meses, 46,XY, com ambiguidade genital (hipospadia peniana, testículo à direita e gônada disgenética à esquerda). FISH de linfócitos e mucosa oral identificou o cariótipo 45, $\mathrm{X} / 46, \mathrm{XY}$, levando ao diagnóstico de disgenesia gonadal mista. $O$ caso 3 é um rapaz de 19 anos, 47,XYY, com atraso de desenvolvimento neuromotor, dificuldade de aprendizado, problemas psicológicos, alta estatura, testículos pequenos, gonadotrofinas elevadas e azoospermia. FISH de linfócitos e mucosa oral identificou a constituição 47,XYY/48,XXYY. Os casos 1 e 2 ilustram a variabilidade fenotípica do mosaico 45,X/46,XY e a importância da detecção da linhagem 45,X na avaliação e na condução dos casos. No caso 3, a função gonadal anormal pôde ser explicada pela linhagem 48,XXYY. O uso de FISH na prática clínica é particularmente relevante quando a análise citogenética clássica traz resultados normais ou incertos em pacientes com quadro sugestivo de uma aneuploidia de cromossomos sexuais. Arq Bras Endocrinol Metab. 2012;56(8):545-51
Departamento de Genética Médica, Faculdade de Ciências Médicas, Universidade Estadual de Campinas (FCM-Unicamp), Campinas, SP, Brazil

${ }^{2}$ Grupo Interdisciplinar de Estudos da Determinação e Diferenciação do Sexo (GIEDDS), FCMUnicamp, Campinas, SP, Brazil ${ }^{3}$ Departamento de Pediatria, Unidade de Endocrinologia Pediátrica, FCM-Unicamp, Campinas, SP, Brazil ${ }^{4}$ Departamento de Pediatria, Unidade de Endocrinologia Pediátrica, Escola Paulista de Medicina, Universidade Federal de São Paulo (UnifespEPM), São Paulo, SP, Brazil

Correspondence to: Andréa Trevas Maciel-Guerra Departamento de Genética Médica, FCM-Unicamp 13083-887 - Campinas, SP, Brazil atmg@uol.com.br

Received on July/31/2012 Accepted on Oct/4/2012 


\section{INTRODUCTION}

Cex chromosome anomalies are the most frequent $\checkmark$ chromosome abnormalities in newborns, with an overall incidence of 1:448 (1). They can be either structural or numerical, and the latter comprise monosomy $(45, \mathrm{X}$ or Turner syndrome) and polysomies $(47, \mathrm{XXY}$ or Klinefelter syndrome; 47,XXX; 47,XYY and rare cases of 48,XXXX; 48,XXXY; 48,XXYY; 49,XXXXX; and 49,XXXXY chromosome constitutions) (2). While individuals with a $47, \mathrm{XXX}$ or $47, \mathrm{XYY}$ karyotype may have few or no physical or developmental problems, in monosomy and other polysomies, the clinical picture usually include growth disorders, primary hypogonadism and (or) multiple congenital anomalies; mental deficiency and behavioral problems are also frequent features in polysomies with more than three sex chromosomes (2-7) (Table 1).

Mosaicism in sex chromosome anomalies can be present in a variety of combinations. This is particularly true in TS, in which about $5 \%$ of the cases may have normal or structurally abnormal $\mathrm{Y}$ chromosome in the karyotype, e.g., 45,X/46,XY; 45,X/47,XYY; and $45, \mathrm{X} / 46$,idic $(\mathrm{Y})(8,9)$. Mosaicism with a $45, \mathrm{X}$ cell line and a second cell line containing a normal or abnormal Y chromosome leads to a wide spectrum of phenotypes, including streak gonads and female genitalia, dysgenetic testes and sex ambiguity, and normal virilized male with infertility. In addition, these patients may have somatic anomalies characteristic of TS (10). Other mosaics of sex chromosome anomalies, including monosomic, normal and (or) polisomic cell lines, may lead to intermediate phenotypes (2).

Fluorescence in situ hybridization (FISH) is a cytogenetic technique used to detect and localize the presence or absence of specific DNA sequences on chromosomes. It has been incorporated to clinical practice as a valuable tool for the identification and definition of chromosome abnormalities, and can be applied to metaphase chromosomes preparations and (or) interphase cell nuclei (11).

Within the group of sex chromosome anomalies, FISH analysis has been a complement to classical cytogenetics for the identification of marker chromosomes (12), and for a more specific and sensitive detection of mosaicism $(13,14)$. Moreover, the study of mucosa cells has also been proposed as a quick and reliable test for the diagnosis of hidden mosaicism (15). This is particularly relevant when classical cytogenetic analysis brings normal or uncertain results in patients with

Table 1. Main features of numerical sex chromosome anomalies

\begin{tabular}{|c|c|c|c|c|c|c|c|}
\hline Karyotype & Incidence & $\begin{array}{l}\text { Mental } \\
\text { retardation }\end{array}$ & $\begin{array}{l}\text { Behavioral } \\
\text { disorders }\end{array}$ & Stature & Gonadal function & $\begin{array}{l}\text { Congenital anomalies/ } \\
\text { Additional medical problems }\end{array}$ & Ref. \\
\hline $45, X$ & $1: 2,130 \mathrm{~F}$ & - & - & Short & $\begin{array}{l}\text { Hypergonadotropic } \\
\text { hypogonadism }\end{array}$ & $\begin{array}{l}\text { Dysmorphic picture, CV and renal } \\
\text { anomalies, autoimmune disorders }\end{array}$ & 1,2 \\
\hline $47, X X Y$ & $1: 576 \mathrm{M}$ & $\begin{array}{l}\text { Greater frequency } \\
\text { when compared } \\
\text { with normal men }\end{array}$ & $\begin{array}{l}\text { Greater frequency } \\
\text { when compared } \\
\text { with normal men }\end{array}$ & Tall & $\begin{array}{l}\text { Hypergonadotropic } \\
\text { hypogonadism }\end{array}$ & $\begin{array}{l}\text { Minor physical findings, varicose } \\
\text { veins, DVT, diabetes mellitus, } \\
\text { autoimmune disorders }\end{array}$ & $1,2,6$ \\
\hline $47, X Y Y$ & $1: 851 \mathrm{M}$ & $\begin{array}{l}\text { Greater frequency } \\
\text { when compared } \\
\text { with normal men }\end{array}$ & $\begin{array}{l}\text { Greater frequency } \\
\text { when compared } \\
\text { with normal men }\end{array}$ & Tall & Usually normal & Minor physical findings & $1,2,6$ \\
\hline $47, X X X$ & $1: 897 \mathrm{~F}$ & $\begin{array}{l}\text { Greater frequency } \\
\text { when compared } \\
\text { with normal } \\
\text { women }\end{array}$ & $\begin{array}{l}\text { Greater frequency } \\
\text { when compared } \\
\text { with normal } \\
\text { women }\end{array}$ & Tall & $\begin{array}{l}\text { Usually normal } \\
\text { Unknown frequency of } \\
\text { premature ovarian failure }\end{array}$ & $\begin{array}{l}\text { Minor physical findings, } \\
\text { low frequency of genitourinary } \\
\text { anomalies and seizures }\end{array}$ & $1,2,6$ \\
\hline $\begin{array}{l}48, X X X X \\
49, X X X X X\end{array}$ & $?$ & + & Variable & Short & $\begin{array}{l}\text { Hypergonadotropic } \\
\text { hypogonadism }\end{array}$ & Dysmorphic picture, CV anomalies & 6,16 \\
\hline $48, X X Y Y$ & $\begin{array}{l}1: 18,000- \\
1: 40,000 \mathrm{M}\end{array}$ & + & + & Tall & $\begin{array}{l}\text { Hypergonadotropic } \\
\text { hypogonadism }\end{array}$ & $\begin{array}{c}\text { Dysmorphic picture, CV and renal } \\
\text { anomalies, type II diabetes, seizures, } \\
\text { DVT }\end{array}$ & $3,6,7$ \\
\hline $48, X X X Y$ & $1: 50,000 \mathrm{M}$ & + & + & Tall & $\begin{array}{l}\text { Hypergonadotropic } \\
\text { hypogonadism }\end{array}$ & $\begin{array}{c}\text { Dysmorphic picture, CV and renal } \\
\text { anomalies, type II diabetes, seizures, } \\
\text { DVT }\end{array}$ & $4,6,7$ \\
\hline $49, X X X X Y$ & $\begin{array}{c}1: 85,000- \\
1: 100,000 \mathrm{M}\end{array}$ & + & + & Short & $\begin{array}{l}\text { Hypergonadotropic } \\
\text { hypogonadism }\end{array}$ & $\begin{array}{c}\text { Dysmorphic picture, CV and renal } \\
\text { anomalies, type II diabetes, seizures, } \\
\text { DVT }\end{array}$ & $4,6,7$ \\
\hline
\end{tabular}

+ = present; - = absent; CV = cardiovascular; DVT = deep vein thrombosis; $F=$ females; $M$ = males. 
features of sex chromosome aneuploidy. The aim of this study is to describe three cases of sex chromosome anomalies in which the final diagnosis could only be achieved by FISH with specific probes for $\mathrm{X}$ and $\mathrm{Y}$ chromosomes.

\section{SUBJECTS AND METHODS}

\section{Clinical reports}

\section{Case 1}

This girl was referred to the University Hospital of Universidade Federal de São Paulo (Unifesp) at the age of 8 years because of short stature. On physical examination, height was 2.25 standard deviations below the mean, and there were some Turner syndrome stigmata: low posterior hairline, low-set ears, epicanthic folds, high-arched palate, micrognathia, webbed neck, scoliosis, genu varum, and hyperconvex nails. External genitalia were typically female. There were no cardiovascular or renal anomalies; thyroid function and the growth hormone - insulin-like growth factor axis were both normal. Ultrasound examination revealed hypoplastic uterus, and gonads located in the pelvic region.

Her karyotype was 46,XY (50 cells), and sequencing of the SRY gene did not show any mutation. She underwent bilateral gonadectomy, and histopathology revealed streak gonads. Hormone replacement therapy with female hormones began when she was 12 years old.

When the girl was 18 years old, her short stature and TS stigmata, together with the absence of SRY mutations, which could enable the diagnosis of complete XY gonadal dysgenesis, led to FISH analysis of lymphocytes using the alpha-satellite probes for the $\mathrm{X}$ (DXZl) and Y (DYZ3) centromeres, which identified mosaicism with a 45 , X cell line (Figures $\mathrm{IA}$ and $\mathrm{IB}$, Table 2). In addition, there were two red signals from the $\mathrm{Y}$ centromere probe both in metaphase chromosomes and interphase nuclei, indicating an isodicentric $\mathrm{Y}$ chromosome. Thus, the karyotype of the girl was defined as $45, \mathrm{X} / 46, \mathrm{X}, \operatorname{idic}(\mathrm{Y})$, and the diagnosis of Turner syndrome was established.

\section{Case 2}

This 21-month-old boy was referred to the University Hospital of Universidade Estadual de Campinas (Unicamp) because of genital ambiguity. He was born at term from healthy and nonconsanguineous parents after an uneventful pregnancy, with birth weight of 2,850 $\mathrm{g}$ and length $47 \mathrm{~cm}$. He had normal neuromotor development and history of painful urination. He had a normal 6-year-old sister, and family history was unremarkable.

On physical examination, weight $(10.1 \mathrm{~kg})$ was slightly above the $3^{\text {rd }}$ percentile, and height $(77 \mathrm{~cm})$ below the $3^{\text {rd }}$ percentile. He had low-set and posteriorly rotated ears, a $3-\mathrm{cm}$ phallus with chordee, penile hypospadias. The right gonad was palpable in the scrotum, and the left one was not.

Laboratory investigation revealed a 46,XY karyotype $(50$ cells) and prepubertal levels of FSH (1.05 $\mathrm{mIU} / \mathrm{mL}), \mathrm{LH}(<0.1 \mathrm{mIU} / \mathrm{L})$, and testosterone $(<$ $0.02 \mathrm{ng} / \mathrm{mL}$ ). After a human chorionic gonadotropin (hCG) stimulation test (three intramuscular injections of 2000 IU on successive days) testosterone rose to 1.9 $\mathrm{ng} / \mathrm{mL}$, which is consistent with the expected pattern for the male sex.

A few months later, he underwent hypospadias repair and surgical exploration. The left gonad was located near the internal inguinal ring; biopsies of this gonad and its adnexa revealed prepubertal testis, segments of epididimus and uterine tube, and fibromuscular tissue compatible with Müllerian remnants. Further biopsies of the left gonad showed only fibrous tissue devoid of germ cells, while biopsies of the right gonad showed prepubertal testis. The left gonad was then removed, and histopathology revealed a streak gonad.

The child was diagnosed as having XY partial gonadal dysgenesis and was followed up thereafter in the pediatric endocrinology service. Growth deficiency became more pronounced during follow-up, but there were no other associated conditions, and ultrasound examination did not reveal any renal anomalies. At the age of 10.9 years, height was $127.5 \mathrm{~cm} \mathrm{(z}$ $=-2.3$; mean target height: $175 \mathrm{~cm})$, and weight 29.5 $\mathrm{kg}(\mathrm{z}=-1.1)$.

FISH analysis using centromere probes for the $\mathrm{X}$ and $\mathrm{Y}$ chromosomes was done both in lymphocytes and buccal smear cells, and identified mosaicism with a $45, \mathrm{X}$ cell line (Figure 1C, Table 2 ). Thus, the patient's karyotype was found to be $45, \mathrm{X} / 46, \mathrm{XY}$ and his diagnosis was changed to mixed gonadal dysgenesis (MGD).

\section{Case 3}

A 19-year-old boy was referred to the University Hospital of Unicamp due to tall stature, small testes, 
and elevated gonadotropins. He was born at term after an uneventful pregnancy with a birth weight of 2,950 $\mathrm{g}$ and length of $49 \mathrm{~cm}$. He had delayed neuromotor development, learning disabilities, and difficulties in relationship with his peers. There was also a history of right inguinal hernia repair when he was 11 years old. He was the younger of two sons of a consanguineous couple, and there were no similar cases in the family.

On physical examination, height was $194 \mathrm{~cm}(\mathrm{z}=$ 2.43; mean target height: $176 \mathrm{~cm}$ ), and weight $76 \mathrm{~kg}$ $(\mathrm{z}=0.47)$. There was no dysmorphic picture, no gynecomastia, and external genitalia were typically male, with a $11.5-\mathrm{cm}$ phallus (slightly above -2.0 standard deviations), and both testes palpable in the scrotum with reduced volume (right: $12 \mathrm{~cm}^{3}$; left: $10 \mathrm{~cm}^{3}$ ). $\mathrm{Pu}-$ bic hair was on Tanner stage P5.

Laboratory investigation in two different occasions (19 and 19.5 years) revealed high levels of FSH (17 $\mathrm{mIU} / \mathrm{mL}$ and $16.14 \mathrm{mIU} / \mathrm{mL}$, normal male range, $\mathrm{NR}, 1.5-12.4)$, normal to elevated $\mathrm{LH}(8.30 \mathrm{mIU} / \mathrm{mL}$ and $10.65 \mathrm{mIU} / \mathrm{mL}$, NR 1.7-8.6), and normal testosterone ( 16.93 and $11.00 \mathrm{pg} / \mathrm{mL}$; NR 8.8-27.0). His karyotype was $47, \mathrm{XYY}$ ( 50 cells), and sperm count revealed azoospermia.

As the picture of hypergonadotropic hypogonadism, microrchidia, and infertility is not typical of the $47, \mathrm{XYY}$ syndrome, FISH analysis using centromere probes for the $\mathrm{X}$ and $\mathrm{Y}$ chromosomes was done both in lymphocytes and buccal smear cells, and identified mosaicism with a 48,XXYY cell line. Thus, his karyotype was found to be $47, \mathrm{XYY} / 48, \mathrm{XXYY}$. Low level mo- saicism with two other cell lines (46,XY and 47,XXY) was also suggested by the results found in interphase cells from lymphocytes and buccal smear (Figures 1DF, Table 2).

\section{Cytogenetic and FISH analyses}

Chromosome analyses were performed on peripheral blood lymphocytes using standard techniques and Gbanding. FISH studies were performed on blood samples using the alpha-satellite probes for the X (DXZ1) and Y (DYZ3) centromeres from Kreatech Biotechnology in case 1 , and from Cytocell ${ }^{\circledR}$ in cases 2 and 3, according to the manufacturers' instructions.

Our protocol on buccal smear samples was based on Shouman and cols. (17) and was modified as follows: before hybridization, slides were pretreated with 2X SSC for $2 \mathrm{~min}$ at $73^{\circ} \mathrm{C}$, and with pepsin (Sigma) $0.005 \%$ in $10 \mathrm{mM} \mathrm{HCl}$ for $40 \mathrm{~min}$ at $37^{\circ} \mathrm{C}$ (Sigma) to remove excess keratin and cytoplasm; washed with phosphate-buffered saline (PBS IX) and PBS IX supplemented with $37 \%$ formaldehyde; and dehydrated with $70 \%, 85 \%$ and $100 \%$ ethanol for 1 min each. Slides were denatured in $70 \%$ formamide/2X SSC for $2 \mathrm{~min}$ at $73^{\circ} \mathrm{C}$, and dehydrated in washes of $70 \%, 85 \%$ and $100 \%$ ethanol for 1 minute each. After hybridization, slides were washed with $2 \mathrm{X}$ SSC for $5 \mathrm{~min}$ at $37^{\circ} \mathrm{C}$, $0.4 \mathrm{X} \mathrm{SSC} / 0.15 \%$ Tween 20 for $2 \mathrm{~min}$ at $73^{\circ} \mathrm{C}$, and $2 \mathrm{X}$ SSC at room temperature before counterstaining with DAPI (Cytocell $\left.{ }^{\circledR}\right)$.

A hundred to 165 metaphase cells, and 200 to 2,000 interphase cells from peripheral blood lymphocytes and (or) buccal smears were analyzed for each patient.

Table 2. Details of FISH results for each case

\begin{tabular}{|c|c|c|c|c|c|c|}
\hline Parameters & $\begin{array}{c}\text { One X signal } \\
(\%)\end{array}$ & $\begin{array}{l}\text { One } X \text { and one } Y \\
\text { signals } \\
(\%)\end{array}$ & $\begin{array}{l}\text { One } X \text { and two } Y \\
\text { signals } \\
\text { (\%) }\end{array}$ & $\begin{array}{l}\text { Two } X \text { and one } Y \\
\text { signals } \\
(\%)\end{array}$ & $\begin{array}{l}\text { Two } X \text { and two } Y \\
\text { signals } \\
\text { (\%) }\end{array}$ & Total cells \\
\hline \multicolumn{7}{|l|}{ Case 1} \\
\hline Blood metaphase & $25(25)$ & & 75 (75) & & & 100 \\
\hline Blood interphase & 27 (13.5) & & $173(86.5)$ & & & 200 \\
\hline \multicolumn{7}{|l|}{ Case 2} \\
\hline Blood metaphase & $15(10.4)$ & $129(89.6)$ & & & & 144 \\
\hline Blood interphase & $159(15.9)$ & 841 (84.1) & & & & 1000 \\
\hline Buccal cells & $234(23.4)$ & 766 (76.6) & & & & 1000 \\
\hline \multicolumn{7}{|l|}{ Case 3} \\
\hline Blood metaphase & & & $152(92.1)$ & & $13(7.9)$ & 165 \\
\hline Blood interphase & & $62(6.2)$ & $890(89)$ & & $46(4.6)$ & 998 \\
\hline Buccal cells & & $20(4.3)$ & 131 (28.5) & $24(5.2)$ & $285(62)$ & 460 \\
\hline
\end{tabular}



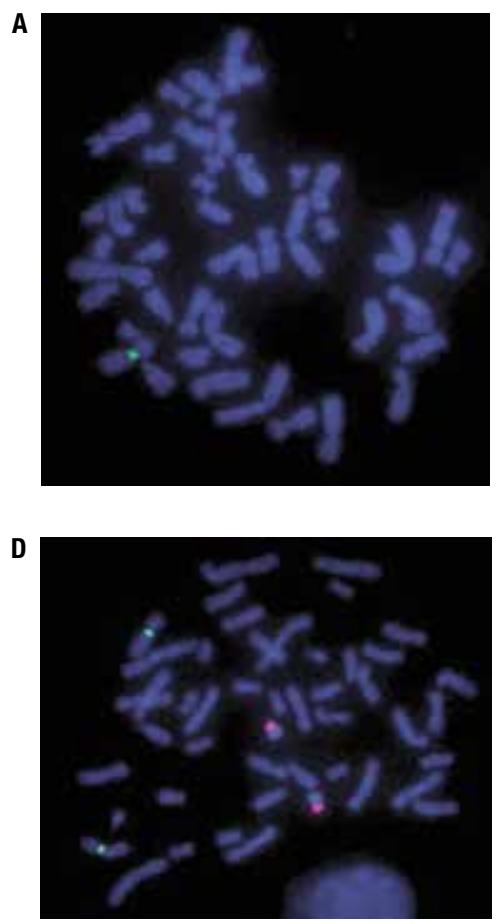

B

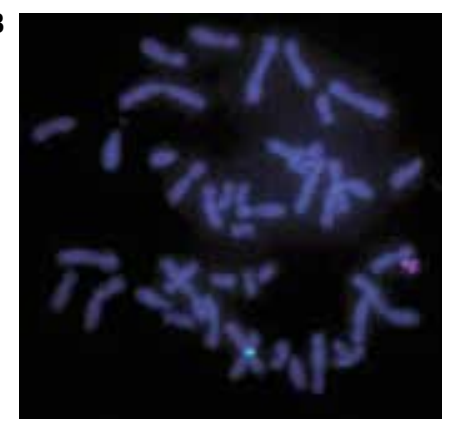

E

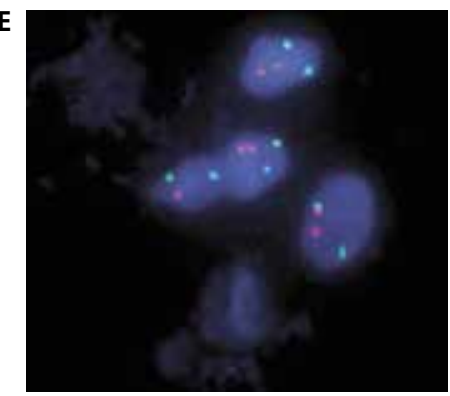

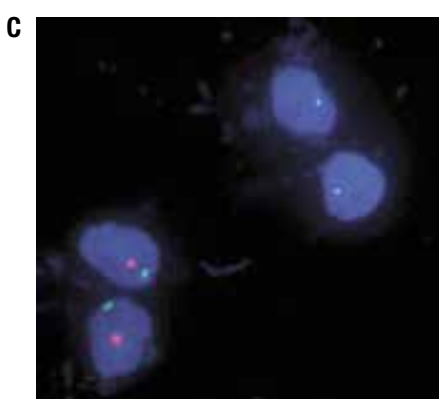

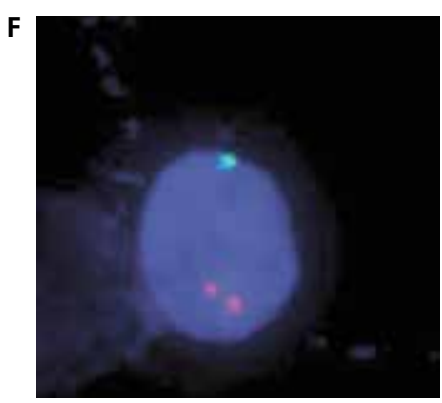

Figure 1. FISH using DXZ1 and DYZ3 probes for $X$ and $Y$ chromosomes centromeres (green and red signals, respectively). A) Case 1: metaphase cell with a 45,X constitution. B) Case 1: metaphase cell with a 46,X,idic(Y) constitution. C) Case 2: interphase cells from buccal smear on the right, showing only one $X$ signal corresponding to the $45, X$ cell line, and others on the left showing one $X$ and one $Y$ signal $(46, X Y)$. D) Case 3: metaphase cell with a 48,XXYY constitution. E) Case 3: interphase cells from buccal smear showing two $X$ and two $Y$ signals corresponding to the $48, X X Y Y$ cell line, and a cell showing two $X$ and one $Y$ signals $(47, X X Y)$. F) Case 3: interphase cell from buccal smear showing one $X$ and two $Y$ signals corresponding to the $47, X Y Y$ cell line. Original magnification $\times 1,000$.

\section{DISCUSSION}

Chromosomal mosaicism is defined as the presence of two or more karyotypically different cell lines in the same individual, and is the result of post-zygotic nondisjunction, anaphase lag, or structural rearrangement. If it occurs when the embryo has only a few cells, mosaicism is more evenly spread throughout the body and may be detectable in most cell lines and resulting tissues; when it occurs in a cell after extensive differentiation, mosaicism may be confined to only one or few tissues.

Cases 1 and 2 illustrate the phenotypic variability of the $45, \mathrm{X} / 46, \mathrm{XY}$ mosaicism, and the differential diagnosis that may arise during investigation. The absence of a $45, \mathrm{X}$ cell line in the classical karyotype indicated, in case 1 , the hypothesis of $46, \mathrm{XY}$ complete gonadal dysgenesis (XY CGD), characterized by streak gonads and female internal and external genitalia and, in case 2, 46,XY partial gonadal dysgenesis (XY PGD), characterized by the finding of two dysgenetic testes, or a dysgenetic testis and a streak gonad and genital ambiguity (18). In both disorders, there may be mutations in the $S R Y$ gene $(19,20)$ (which are more frequent in XY CGD) or the NR5Al gene $(21,22)$, but the origin may also be unknown (which is more frequent in XY PGD). Also, in both disorders, streak gonads must be removed, as well as dysgenetic testes that are not located in the scrotal folds, due to the high risk of neoplastic transformation (gonadoblastomas and dysgerminomas) (23).

Growth deficiency was the main clinical feature indicating the possibility of hidden mosaicism in both cases, together with dysmorphic features suggestive of TS in case 1 . The use of FISH enabled these hypotheses to be confirmed, also enabling proper management and follow-up of the children. In case 1 , final diagnosis was TS, defined cytogenetically by the presence of an $\mathrm{X}$ chromosome, and total or partial absence of the second sex chromosome; and defined clinically by a female phenotype with short stature and primary hypogonadism in most cases, highly variable dysmorphic picture, and associated conditions, such as cardiovascular and renal anomalies and hypothyroidism (24).

In case 2 , the final diagnosis of MGD was based on partial testicular dysgenesis and genital ambiguity in- 
distinguishable from that of XY PGD, but associated with a 45,X/46,XY karyotype, and TS features (25). Thus, management and follow-up must be identical to those of TS; in addition, in both TS and MGD, the use of growth hormone may lead to improvement in final height $(24,25)$. Regarding sex hormone replacement, female hormones are necessary in most cases of TS, and in the cases of MGD reared as females, in whom bilateral gonadectomy must be performed. On the other hand, in patients with MGD with a male sex assignment, maintenance of at least one testis may allow spontaneous male puberty, though secondary failure of Leydig cells may require therapy with testosterone (25).

The use of FISH in case 1 also enabled the detection of a structural anomaly of the $\mathrm{Y}$ chromosome (dicentrism), which is frequently observed in $45, \mathrm{X} / 46, \mathrm{XY}$ mosaicism (26), and had not been described in classical karyotypying of the girl. This anomaly predisposes to the loss of the $\mathrm{Y}$ chromosome during mitotic divisions, thus generating the $45, \mathrm{X}$ cell line (27).

In case 3 , delayed neuromotor development, learning disabilities and psychological problems, though infrequent in 47,XYY syndrome, were compatible with this chromosome constitution. However, low testicular volume, hypergonadotropic hypogonadism, and azoospermia are not usually found in individuals with this karyotype. The detection of the 48,XXYY cell line by FISH explained these findings, which are common in this polysomy (Table 1). In individuals with chromosomal mosaicism the proportion of normal to abnormal cell lines usually varies among tissue types (28), and this was also observed in case 3 .

Few cases of $47, \mathrm{XYY} / 48, \mathrm{XXYY}$ mosaicism are found in literature $(29,30)$; the clinical picture of two of them (29) was very similar to the present case: tall stature, mental retardation, behavior problems, and physical features of Klinefelter syndrome.

The finding of this second cell line in case 3 did not modify the management of this patient, who needs monitoring of testosterone levels and, if necessary, androgen replacement (7), though there may be concerns about worsening of behavior with this therapy (31).

It is worth commenting that the proportion of $45, \mathrm{X}$ cell line in metaphases analyzed by FISH in cases 1 and $2(25 \%$ and $10 \%$, respectively) was greater than expected when one considers that the analysis of 50 cells in the karyotype in both cases enabled the exclusion of mosaicism equal to $6 \%$ or greater, with $95 \%$ confidence (32). However, FISH analysis was done many years af- ter karyotyping in both cases ( 10 years in case 1 , and 9 years in case 2). As already pointed out, structural anomaly of the $\mathrm{Y}$ chromosome in case 1 predisposes to loss of this chromosome during mitotic divisions (27), and this continuous loss may lead to an increasing proportion of the $45, \mathrm{X}$ cell line. Regarding case 2 , in vivo studies have shown that the percentage of mosaicism in TS can change dramatically over time $(33,34)$.

Although FISH has been widely used in research, this technique is rarely used in clinical practice to evaluate individuals whose clinical picture is suggestive of a sex chromosome anomalies, since most cases may be solved by classical karyotyping. However, FISH is a useful tool to investigate atypical cases, such as the ones described here. The clinician must keep in mind that mosaicism is a frequent feature of sex chromosome anomalies, particularly TS, and that the use of FISH also in interphase cells from buccal smears may extend the investigation to a different tissue, replacing skin biopsy and fibroblast culture in a reliable, fast, and noninvasive manner (35).

Acknowledgments: we are grateful to the Cytogenetics Laboratory of the Department of Medical Genetics of Universidade Estadual de Campinas (Unicamp). This study was supported by Fundação de Amparo à Pesquisa do Estado de São Paulo (Fapesp) $(2011 / 50189-7)$.

Disclosure: no potential conflict of interest relevant to this article was reported.

\section{REFERENCES}

1. Nielsen J, Wohlert M. Sex chromosome abnormalities found among 34,910 newborn children: results from a 13-year incidence study in Arhus, Denmark. Birth Defects Orig Artic Ser. 1990;26(4):209-223.

2. Li X. Sex chromosomes and sex chromosome abnormalities. Clin Lab Med. 2011;31(4):463-79.

3. Sørensen K, Nielsen J, Jacobsen P, Rølle T. The $48, X X Y Y$ syndrome. J Ment Defic Res. 1978;22(3):197-205.

4. Kleczkowska A, Fryns JP, Van den Berghe H. X-chromosome polysomy in the male. The Leuven experience 1966-1987. Hum Genet. 1988;80(1):16-22.

5. Linden MG, Bender BG, Robinson A. Intrauterine diagnosis of sex chromosome aneuploidy. Obstet Gynecol. 1996;87(3):468-75.

6. Ottesen AM, Aksglaede L, Garn I, Tartaglia N, Tassone F, Gravholt $\mathrm{CH}$, et al. Increased number of sex chromosomes affects height in a nonlinear fashion: a study of 305 patients with sex chromosome aneuploidy. Am J Med Genet A. 2010;152A(5):1206-12.

7. Tartaglia N, Ayari N, Howell S, D'Epagnier C, Zeitler P. 48,XXYY, $48, X X X Y$ and $49, X X X X Y$ syndromes: not just variants of Klinefelter syndrome. Acta Paediatr. 2011;100(6):851-60.

8. Oliveira RM, Verreschi IT, Lipay MV, Eça LP, Guedes AD, Bianco B. $Y$ chromosome in Turner syndrome: review of the literature. Sao Paulo Med J. 2009;127(6):373-8. 
9. Barros BA, Maciel-Guerra AT, De Mello MP, Coeli FB, Carvalho AB, Viguetti-Campos N, et al. The inclusion of new techniques of chromosome analysis has improved the cytogenetic profile of Turner syndrome. Arq Bras Endocrinol Metab. 2009;53(9):1137-42.

10. Ogata T, Matsuo N. Turner syndrome and female sex chromosome aberrations: deduction of the principal factors involved in the development of clinical features. Hum Genet. 1995;95:607-9

11. Tsuchiya KD. Fluorescence in situ hybridization. Clin Lab Med. 2011;31(4):525-42.

12. Sallai A, Sólyom J, Dobos $M$, Szabó J, Halász Z, Ságodi L, et al. Y-chromosome markers inTurner syndrome: Screening of 130 patients. J Endocrinol Invest. 2010;33(4):222-7.

13. Wiktor $A E$, Van Dyke DL. Detection of low level sex chromosome mosaicism in Ullrich-Turner syndrome patients. Am J Med Genet A. $2005 ; 138(3): 259-61$.

14. Garcia-Quevedo L, Blanco J, Sarrate Z, Català V, Bassas L, Vidal F. Hidden mosaicism in patients with Klinefelter's syndrome: implications for genetic reproductive counselling. Hum Reprod. 2011;26(12):3486-93

15. Westlander G, Ekerhovd E, Granberg S, Hanson L, Hanson C, Bergh C. Testicular ultrasonography and extended chromosome analysis in men with nonmosaic Klinefelter syndrome: a prospective study of possible predictive factors for successful sperm recovery. Fertil Steril. 2001;75:1102-5.

16. Schoubben E, Decaestecker K, Quaegebeur K, Danneels L, Mortier G, Cornette L. Tetrasomy and pentasomy of the $\mathrm{X}$ chromosome. Eur J Pediatr. 2011;170(10):1325-7.

17. Shouman N, Pabst B, Arslan-Kirchner M, Eckardt A, Schönweiler $R$, Ptok $M$, et al. Search for deletion 22q11.2 in interphase nuclei of buccal mucosa of patients ascertained by isolated cleft palate: a new diagnostic approach. Int J Oral Maxillofac Surg. 2003;32(2):198-200.

18. Mendonca BB, Domenice S, Arnhold IJ, Costa EM. 46,XY disorders of sex development (DSD). Clin Endocrinol (Oxf). 2009;70(2):173-87

19. Rocha VB, Guerra-Júnior G, Marques-de-Faria AP, de Mello MP, Maciel-Guerra AT. Complete gonadal dysgenesis in clinical practice: the 46,XY karyotype accounts for more than one third of cases. Fertil Steril. 2011;96(6):1431-14.

20. Hawkins JR, Taylor A, Goodfellow PN, Migeon CJ, Smith KD, Berkovitz GD. Evidence for increased prevalence of SRY mutations in $X Y$ females with complete rather than partial gonadal dysgenesis. Am J Hum Gen. 1992;51:979-84.

21. Ferraz-de-Souza B, Lin L, Achermann JC. Steroidogenic factor-1 (SF-1, NR5A1) and human disease. Mol Cell Endocrinol. 2011;336(1-2):198-205.
22. Soardi FC, Coeli FB, Maciel-Guerra AT, Guerra-Junior G, Mello MP. Complete XY gonadal dysgenesis due to p.D293N homozygous mutation in the NR5A1 gene: a case study. J Appl Genet. 2010;51:223-4.

23. Cools M, Drop SL, Wolffenbuttel KP, Oosterhuis JW, Looijenga LH. Germ cell tumors in the intersex gonad: old paths, new directions, moving frontiers. Endocr Rev. 2006;27(5):468-84.

24. Bondy CA. Turner Syndrome Study Group. Care of girls and women with Turner syndrome: a guideline of the Turner Syndrome Study Group. J Clin Endocrinol Metab. 2007;92:10-25.

25. Lindhardt Johansen $M$, Hagen $C P$, Rajpert-De Meyts $E$, Kjærgaard S, Petersen BL, Skakkebæk NE, et al. 45, X/46,XY mosaicism: phenotypic characteristics, growth, and reproductive function - A retrospective longitudinal study. J Clin Endocrinol Metab. 2012;97(8):E1540-9.

26. Bettio D, Venci A, Rizzi N, Negri L, Setti PL. Clinical and molecular cytogenetic studies in three infertile patients with mosaic rearrangedY chromosomes. Hum Reprod. 2006;21(4):972-5.

27. Hsu LY. Phenotype/karyotype correlations of $Y$ chromosome aneuploidy with emphasis on structural aberrations in postnatally diagnosed cases. Am J Med Genet. 1994;53:108-40.

28. Nazarenko SA, Timoshevsky VA, Sukhanova NN. High frequency of tissue-specific mosaicism in Turner syndrome patients. Clin Genet. 1999;56(1):59-65.

29. Spencer DA, Eyles JW, Mason MK. XYY syndrome, and XYY/ XXYY mosaicism also showing features of Klinefelter's syndrome. J Med Genet. 1969;6:159-65.

30. Stochholm K, Juul $\mathrm{S}$, Gravholt $\mathrm{CH}$. Diagnosis and mortality in 47,XYY persons: a registry study. Orphanet J Rare Dis. 2010;5:15.

31. Tartaglia N, Davis S, Hench A, Nimishakavi S, Beauregard R, Reynolds $A$, et al. A new look at XXYY syndrome: medical and psychological features. Am J Med Genet A. 2008;146(12):1509-22.

32. Hook EB. Exclusion of chromosome mosaicism: tables of 90 percent, 95 percent and 99 percent confidence limits and comments on use. Am J Hum Genet. 1977;29:94-7.

33. McCorquodal MM, Bowdle FC. Two pregnancies and the loss of the $46, X X$ cell line in a $45, X / 46, X X$ Turner mosaic patient. Fertil Steril. 1985;43:229-33.

34. Gravholt $\mathrm{CH}$, Friedrich $\mathrm{U}$, Nielsen J. Chromosomal mosaicism: a follow-up study of 39 unselected children found at birth. Hum Genet. 1991;88:49-52.

35. Schad CR, Kuffel DG, Wyatt WA, Zinsmeister AR, Jenkins RB, Dewald GW, et al. Application of fluorescent in situ hybridization with $X$ and $Y$ chromosome specific probes to buccal smear analysis. Am J Med Genet. 1996;66(2):187-92. 